\title{
Can the Treasury Exempt its Own Companies from Tax? The \$45 Billion GM NOL Carryforward
}

\section{Citation}

J. Mark Ramseyer and Eric B. Rasmusen, Can the Treasury Exempt its Own Companies from Tax? The $\$ 45$ Billion GM NOL Carry forward, 1 Cato Papers Pub. Pol'y 1 (2011).

\section{Published Version}

http://object.cato.org/sites/cato.org/files/serials/files/cato-papers-public-policy/2011/11/ cpppvol1article1.pdf

\section{Permanent link}

http://nrs.harvard.edu/urn-3:HUL.InstRepos:30012793

\section{Terms of Use}

This article was downloaded from Harvard University's DASH repository, and is made available under the terms and conditions applicable to Open Access Policy Articles, as set forth at http:// nrs.harvard.edu/urn-3:HUL.InstRepos:dash.current.terms-of-use\#OAP

\section{Share Your Story}

The Harvard community has made this article openly available.

Please share how this access benefits you. Submit a story.

\section{Accessibility}


ISSN 1936-5349 (print)

ISSN 1936-5357 (online)

\title{
HARVARD
}

JOHN M. OLIN CENTER FOR LAW, ECONOMICS, AND BUSINESS

\author{
CAN THE TREASURY EXEMPT \\ ITS OWN COMPANIES FROM TAX? \\ THE \$45 BILLION GM NOL CARRYFORWARD
}

J. Mark Ramseyer \& Eric B. Rasmussen

Discussion Paper No. 690

$04 / 2011$

Harvard Law School

Cambridge, MA 02138

This paper can be downloaded without charge from:

The Harvard John M. Olin Discussion Paper Series: http://www.law.harvard.edu/programs/olin_center/

This paper is also a discussion paper of the

John M. Olin Center’s Program on Corporate Governance. 
JEL Classifications: H3, H5, K2, L5

\title{
Can the Treasury Exempt its Own Companies from Tax? The \$45 Billion GM NOL Carryforward
}

\author{
April 15, 2011
}

\author{
J. Mark Ramseyer and Eric B. Rasmusen
}

\begin{abstract}
To discourage firms from trying to buy and sell tax deductions, Sec. 382 of the tax code limits the ability of a firm that acquires another company to use the target's "net operating losses" (NOLs). Under the Troubled Asset Relief Program (TARP), the Treasury lent a large amount of money to GM. In bankruptcy, it then agreed to trade that debt for stock.

GM did not make many cars anyone wanted to buy, but it did have $\$ 45$ billion in NOLs. Unfortunately for the firm, if the Treasury now sold the stock it acquired in bankruptcy it would trigger those Sec. 382 NOL limitations. Suppose the newly reorganized GM did start making cars that consumers wanted. It would be able to use only a modest portion of its old NOL's -- if any.

Treasury "solved" this problem by issuing a series of "Notices" in which it announced that the law did not apply. On its terms, Sec. 382 states that the NOL limits apply whenever a firm's ownership changes. That rule, the Treasury declared, did not apply to itself. Notwithstanding the straightforward and all-inclusive statutory language, GM would be able to continue to use its NOLs in full after the Treasury sold its stock.

The Treasury had no legal or economic justification for these Notices, which applied to Citigroup and AIG as well as to GM. Nonetheless, the Notices largely escaped public attention -even though they potentially transferred substantial wealth to the most loyal of the administration's supporters (the UAW). That it could do so illustrates the risk involved in this kind of manipulation. We suggest that Congress give its members standing to challenge such manipulation in court.
\end{abstract}

J. Mark Ramseyer is the Mitsubishi Professor, Harvard Law School, Cambridge, MA 02138. ramseyer@law.harvard.edu. 617-496-4878.

Eric B. Rasmusen is the Dan R. \& Catherine M. Dalton Professor, Department of Business Economics and Public Policy, Kelley School of Business, Indiana University, Bloomington, IN 47405, erasmuse@indiana.edu. Secretary: 812-855-9219. Iphone: 812-327-6695. Fax: 812-855-3354. 


\title{
Can the Treasury Exempt its Own Companies from Tax? The $\$ 45$ Billion GM NOL Carryforward
}

\author{
(C) 2011. J. Mark Ramseyer and Eric B. Rasmusen. All Rights Reserved
}

“Dona clandestinasunt semper suspiciosa”1

\section{Introduction}

Year after year, General Motors lost money -- enormous sums of money. It designed cars. It built cars. But no one wanted to buy the cars it designed and built. Over time, it accumulated huge operating losses ("net operating losses," or NOLs). The tax code let GM carry forward these NOLs into the future. It let the firm save them for that day in the future when it would once again sell cars that people wanted.

The day never came. Instead, in June 2009 GM (or “Old GM”) declared bankruptcy. It filed under Chapter 11 of the Bankruptcy Code and sold its assets to a new shell (New GM) in a transaction under Sec. 363 of the Code. Old GM's shareholders were not part of new GM, and the firm's creditors took stock: the US Treasury, the auto unions, and Canada swapped debt claims against Old GM for equity stakes in New GM. With 61 percent, the Treasury took the largest share among this group. Other Old GM creditors acquired a 10 percent stake in New GM as well. In the fall of 2010, Treasury re-sold a large amount of its New GM shares to the public, and cut its share to $26 \%$.

New GM has the factories, offices, designs and some of the workers that Old GM had. It also acquired some $\$ 18$ billion worth of its NOLs. ${ }^{2}$ It could not use them to

\footnotetext{
${ }^{1}$ Sir Edward Coke, “Twyne’s Case,” 3 Coke, 80 b. (Star Chamber, 1602), in Evans Holbrook \& Ralph William Aigler, Cases on the Law of Bankruptcy: Including the Law of Fraudulent Conveyances153-57 (1915), Google Books, http://books.google.com/. Twyne’s Case was about a fraudulent conveyance by an insolvent debtor to a friendly creditor. Another passage from the case will be apt when we consider the relationship between statute and regulation:

"To one who marvelled what should be the reason that Acts and statutes are continually made at every Parliament without intermission, and without end; a wise man made a good and short answer, both of which are well composed in verse.
}

Quaeritur, utcrescitunt tot magna voluminalegis?

In promptucausaest, orescit in orbedolu

And because fraud and deceit abound in these days more than in former times, it was resolved in this case by the whole Court, that all statutes made against fraud should be liberally and beneficially expounded to suppress the fraud."

${ }^{2}$ The losses themselves were $\$ 45$ billion; their book value as an asset is listed as $\$ 18$ billion. We will use the figure $\$ 18$ billion even though it is too high because standard accounting rules for tax assets are absurdly inaccurate. They are inaccurate for two reasons. First, GAAP requires companies to not discount for the time value of money. If a company expects to save $\$ 1$ million in taxes in 16 years using deferred tax losses, it records that as a current tax asset worth $\$ 1$ million, even though the present discounted value 
reduce its corporate income tax liability immediately -- it earned no income against which to apply them. But in 2010 New GM did finally turn a profit. Presumably, it will now start using its NOL's to avoid its corporate tax. ${ }^{3}$

Ordinarily, when one company buys another's assets, it does not acquire its tax losses too. But the sale from Old GM to New GM qualified as a tax-free reorganization under Sec. 368 of the tax code: neither Old GM nor New GM incurred a tax liability, New GM entered Old GM's assets on its books with Old GM's "adjusted basis," and New GM acquired Old GM's NOLs.

The problem lay in Treasury's planned sale of the shares it acquired in New GM. If the combined equity stake of any group of shareholders in a "loss corporation" like New GM climbs by more than 50 percentage points, Sec. 382 of the tax code limits the firm's ability to use those accumulated NOLs. Given Treasury's large stake in New GM, if it sold its entire stake to the public, those new owners would raise their combined interest by 50 points. They would buy Treasury's shares, and New GM would lose its ability to avoid taxes on any future income.

To solve this problem, the Treasury issued a series of "Notices." The Sec. 382 rules, it declared, would not apply to itself. When it sold its shares in New GM, its buyers might increase their ownership stake by 50 percentage points, but they would not trigger the Sec. 382 limits. The tax code offered no exception for government-owned shares, and the Treasury did not purport to find one. Instead, it just declared that the law did not apply. ${ }^{4}$

Several of these Notices also apply to AIG and Citigroup. Through the TARP transactions, both firms experienced ownership changes over 50\%. Ordinarily, they would lose their NOLs. If they retained them the government would lose obviously revenue, but that loss would be offset in part by the higher price it would receive on its shares.

We do not address the wisdom of the bailouts. Neither do we ask whether giving a multi-billion-dollar tax break to an automobile or financial company makes sense. Instead, we focus on the propriety of the Treasury's manufacturing a tax break. More generally, we focus on the wisdom of giving a President the ability to invent a tax deduction for his political supporters without answering to the courts or Congress.

Recall Holmes's description of the law as the "Bad Man's" prediction about whether a judge would stop him: ${ }^{5}$

(at 5\% interest) is only $\$ 458,000$. Second, even if there is a good chance that the company will never make a profit again, it records the full amount if "it is more likely than not" that the company will someday make enough profit. Thus, if the company just mentioned estimated that its chances of failure before 16 years from now was a mere $49 \%$, it would still record the $\$ 1$ million as $\$ 1$ million, not $\$ 510,000$ or $\$ 233,580$. For a critical view of this rule see J. Edward Ketz, Deferred Income Taxes Should be Put to Rest,SmartPros, at http://accounting.smartpros.com/x68912.xml (March 2010).

3 “Resurgent G.M. Posts 2010 Profit of \$4.7 Billion,” New York Times, February 4, 2011, at http://www.nytimes.com/2011/02/25/business/25auto.html

4 The last was: Internal Revenue Service Notice 2010-2, “Application of Section 382 to Corporations Whose Instruments are Acquired and Disposed of by the Treasury Department under Certain Programs Pursuant to the Emergency Economic Stabilization Act of 2008,” 2010-2 I.R.B. 251, http://www.irs.gov/irb/2010-02_IRB/ar09.html.

${ }^{5}$ Oliver Wendell Holmes, Jr..The Path of the Law, 10 Harvard Law Review 457 (1897). 
If you want to know the law and nothing else, you must look at it as a bad man [would look at it, a man] ... who cares only for the material consequences which such knowledge enables him to predict, not as a good one, who finds his reasons for conduct, whether inside the law or outside of it, in the vaguer sanctions of conscience. ... [I]f we take the view of our friend the bad man we shall find that he does not care two straws for the axioms or deductions, but that he does want to know what the Massachusetts or English courts are likely to do in fact. I am much of this mind. The prophecies of what the courts will do in fact, and nothing more pretentious, are what I mean by the law.

If a President is Holmes's Good Man, he will obey the Constitution because it is the Constitution. The Treasury gave General Motors an illegal tax break. As a Good Man (and former law professor), the President will read our article, feel remorse, and fire everyone involved.

If a President is Holmes's Bad Man, he will obey the Constitution only when a court can make him obey it. If he hears of our article, he will ignore it. As a lawyer, he knows that nobody has standing to challenge someone else's tax benefits in court. Thus, his "prophecy about what a court will do" is easy: Nothing. The courts will reject any challenge for lack of standing, whatever the merits of a claim might be.

Only potential bad publicity would worry a Bad Man President. But publicity he can skirt by giving the funds through exemptions from the application of Sec. 382 of the tax code to limits on carryforwards of NOLs following a sale under Sec. 363 of the Bankruptcy Code that uses preferred stock, credit bidding, and warrants by one company named GM to a different company also named GM. Giving a billion dollars in cash to the UAW would be obvious. Giving it through a Sec. 382 exemption will put his critics to sleep.

In the article that follows, we explain the intricacies of the tax break (Sec. II). We discuss the law involved (Sec. III). If you think all Presidents are Good Men, you may stop reading at that point. After all, following the Constitution is just a matter of understanding it. We explain it, you understand it, end of story. Lest some Presidents be Bad Men, however, we conclude by exploring procedural reforms Congress might adopt to prevent a recurrence of what happened with GM.

\section{What Happened}

A. The Detail:

General Motors was a public corporation with much unsecured debt, including \$21 billion owed to the UAW Trust on behalf of retired workers and \$27 billion owed to bondholders. None of these stakeholders was senior enough to see much return if the company liquidated in pieces. Probably, none would see much return even if the firm found a buyer for the whole company.

The senior creditors were a diverse lot. The U.S. Treasury had a secured interest in $\$ 19.4$ billion from TARP loans, and $\$ 30.1$ billion in other loans. The Canadian government held secured claims of $\$ 9.2$ billion. And private creditors held another $\$ 5.9$ billion in secured loans. Government senior debt thus totaled \$58.7 billion.

GM filed for bankruptcy under Chapter 11 of the Bankruptcy Code. To restructure its finances, it then negotiated a sale under Sec. 363 of the Code. For this transaction, it (Old GM) formed New GM as a shell and sold its assets to it. In exchange 
for its $\$ 21$ billion unsecured debt to Old GM, the UAW Trust received 17.5 percent of the common stock of New GM, \$6.5 billion in preferred stock, and \$2.5 billion in debt. In exchange for their $\$ 27$ billion unsecured debt, the other unsecured creditors received 10 percent of the common stock of New GM and warrants for another 15 percent. The private secured creditors (the $\$ 5.9$ billion claim) were paid in full. The Canadian government received 12 percent of the New GM common stock, and the U.S. Treasury received interests detailed shortly below.

To consider the stakes involved, note that in December 2010 New GM had stock worth $\$ 54.4$ billion and liabilities of $\$ 12.9$ billion, ${ }^{6}$ for a total asset value of $\$ 67.3$ billion. In effect, the sale price in the 363 offer was: (a) $\$ 58.7$ billion in senior credit claims, (b) $\$ 5.9$ billion paid to private secured creditors, (c) $\$ 5.4$ billion in stock (10 percent of $\$ 54.4$ billion), and (d) a portfolio of harder-to-value warrants. This yields a total of $\$ 67$ billion plus warrants. ${ }^{7}$

Apparently, the 363-sale buyers paid $\$ 67$ billion plus the warrant value for assets worth $\$ 67.3$ billion. That seems a remarkably high price, considering that no other bidder loomed on the horizon. The bankruptcy judge would seem to deserve praise for extracting so much value for Old GM's creditors.

This $\$ 67.3$ billion in asset value is not the net benefit to the 363-sale buyers or the senior creditors, however. That benefit depends on who owns the New GM equity and debt. Old GM's private secured creditors received \$5.9 billion in cash for their \$5.9 billion in debt. The Canadian government gave up its $\$ 9.2$ billion in Old GM debt, but took a $12 \%$ stake in the common (stock worth $.12(54.4)=\$ 6.5$ billion) plus $\$ 0.4$ billion in preferred stock plus $\$ 1.3$ billion in debt in New GM -- for a total value of $\$ 8.2$ billion. The UAW trust gave up unsecured claims of $\$ 21$ billion and received:

(i) $17.5 \%$ of the stock of New GM worth .175*54.4 = $\$ 9.5$ billion,

(ii) $\$ 6.5$ billion in preferred stock, and

(iii) $\$ 2.5$ billion in debt,

for a total of $\$ 18.5$ billion. Given that the UAW trust had been a junior creditor, this was a very good deal. By contrast, the other unsecured creditors gave up claims of \$27 billion for 10 percent of the common stock and warrants.

Recall that the U.S. Treasury had debt claims totaling \$49.5 billion. In exchange for those claims, it took 61 percent of the stock in New GM (stock worth .61 $(\$ 54.4$ billion)= \$33.2 billion), $\$ 2.1$ billion in preferred stock, and a $\$ 6.7$ billion debt claim against New GM. All told, it received compensation of $\$ 42$ billion.

Focus on the U.S. government. Through the Sec. 363 sale, it -- apparently -- lost ( $\$ 49.5$ billion - $\$ 42$ billion $=$ ) $\$ 7.5$ billion. Anyone who loses only ( $\$ 7.5$ billion $/ \$ 49.5$ billion) $=15$ percent on a $\$ 49.5$ billion loan to a failing firm does well indeed. Appearances deceive. The government also gave GM investors $\$ 45$ billion in NOLs. If the 363 sale had not gone through, or the sale had been made to an outside buyer, these NOLs would have disappeared. The book value of these NOLs is \$18 billion. 28, 2010).

${ }^{6}$ CreditSuisse, “General Motors Co”, Christopher J. Ceraso, Robert Moffatt, and ShreyasPati (Dec.

${ }^{7}$ Data in these paragraphs is from A. Joseph Warburton Understanding the Bankruptcies of Chrysler and General Motors: A Primer, 60 Syracuse L. Rev. 531, 536 (2010). 
To be sure, Treasury was giving tax breaks partly to itself, and the book value exceeds the market value of the NOLs since it would take some years for them to be used. If the market value of the NOLs is, say, $\$ 12$ billion (a little under the estimate of the stock analysts that we cite in Section B below), then that $\$ 12$ billion was incorporated into the $\$ 54.4$ billion equity value of the new GM. If so, we have overestimated the overall value of the deal for the Treasury. Of its $\$ 33.2$ billion in stock, 7.32 (=.61(12)) was a tax gift to itself.

More simply, we can start with the $\$ 5$ billion loss we calculated above using the full value of the New GM stock, but subtract an additional $\$ 12$ billion for the tax loss to the Treasury. In that case, the Treasury lent GM $\$ 49.5$ billion, and lost ( $\$ 7.5$ billion + $\$ 12$ billion $) / \$ 49.5$ billion = 39 percent. If only Treasury could have inserted a further secret $\$ 20$ billion of assets into New GM, New GM’s stock price would have been so high that Treasury would have appeared to make a profit from the entire affair.

\section{B. As GM Told it:}

Here is how GM describes its tax situation: ${ }^{8}$

... We recorded valuation allowances against certain of our deferred tax assets, which under ASC 852 also resulted in goodwill. ${ }^{9}$...

In July 2009 with U.S. parent company liquidity concerns resolved in connection with the Chapter 11 Proceedings and the 363 Sale, to the extent there was no other significant negative evidence, we concluded that it is more likely than not that we would realize the deferred tax assets in jurisdictions not in threeyear adjusted cumulative loss positions.

Refer to Note 22 to our audited consolidated financial statements for additional information on the recording of valuation allowances. ${ }^{10}$

\footnotetext{
${ }^{8}$ Amendment No. 2 to Form S-1 Registration Statement under The Securities Act of 1933 General Motors Company, http://www.gm.com/vehicles/results.jsp?useFlash=N.

${ }^{9}$ Amendment No. 2 to Form S-1 Registration Statement under The Securities Act of 1933 General Motors Company, http://www.gm.com/vehicles/results.jsp?useFlash=N. p. 82.

${ }^{10}$ Amendment No. 2 to Form S-1 Registration Statement under The Securities Act of 1933 General Motors Company, http://www.gm.com/vehicles/results.jsp?useFlash=N.p.138.
} 
The following table summarizes the components of temporary differences and carryforwards that give rise to deferred tax assets and liabilities (dollars in millions):

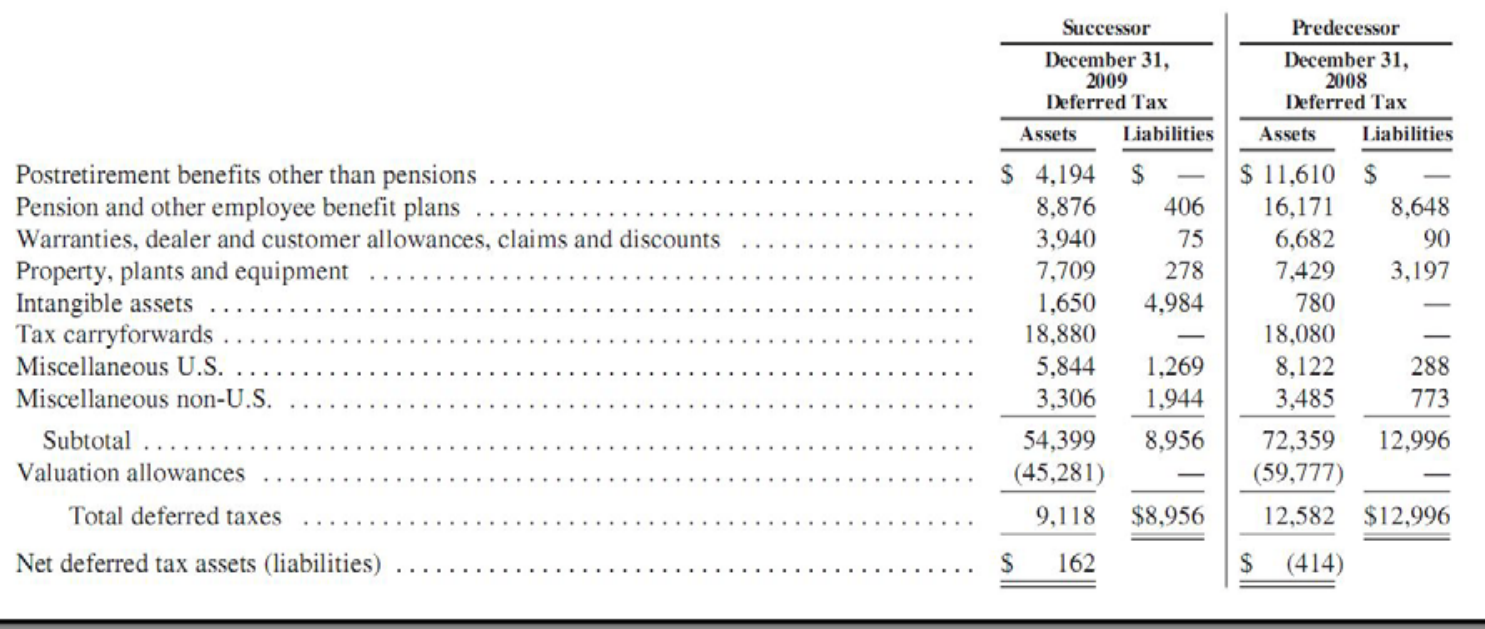

The table above from page F-121 of the 8-K shows that New GM claimed to inherit \$18.08 billion in tax carryforwards from Old GM. ${ }^{11}$ Two stock analysts wrote:

We calculate an NPV of GM's deferred tax assets at \$17.2bn of which $\$ 4 \mathrm{bn}$ is related to pension contributions and more than \$13bn related to accumulated NOLs and tax credits including R\&D credits. ${ }^{12}$

and

Via a special regulation, GM's highly valuable US tax assets (worth \$18.9B in the US at 09-end) were left intact....Our Dec-2011 price target assumes a present value of $\$ 12.4 \mathrm{~B}$ of (2011-ending) non-European global tax assets.... Present-valuing the $\$ 18.6 \mathrm{~B}$ face value figure using a $12 \%$ discount rate (Ford is $8 \%$; we use $12 \%$ for GM to reflect the lower mix of debt in its cap structure), we arrive at a PV for global economic tax assets ex. Europe of $\$ 12.4 \mathrm{~B}$ at 2011-end. ${ }^{13}$ Thus, stock analysts are well aware of the existence and value of the NOL's, though they do estimate the economic value at lower than the accounting value. This is an important element of the political economy of the situation. It was useful that the general public not understand that New GM's value was increased by corresponding tax losses to the government, but it was also important that stock analysts did understand it. If they did not, then when the government sold its stock in GM, it would take a much lower price. Only the other investors -- not Treasury -- would have benefited from the tax assets.

\section{Other Firms:}

Although we focus on GM, Treasury gave legally unauthorized NOLs to two other firms as well. As with GM, it did this by issuing TARP-specific "Notices" about the availability of NOLs. Citigroup, for example, claimed "tax assets" of \$46.1 billion at

${ }^{11}$ Not all these tax carryforwards were necessarily NOLs, strictly speaking. They may also include "built-in losses" on assets that declined in value and unused tax credits.

12 Morgan Stanley, “General Motors Re-In-Car-Nation,” December 28, 2010.

13 J.P. Morgan, General Motors Overweight GM, GM US Reborn, High Octane SAAR and Product Play; Initiate with Overweight (Dec. 28, 2010). 
the end of 2009. In June 2009, Citigroup and the Treasury agreed to exchange the government's preferred stock for common stock. The government acquired a 33.6\% ownership stake. In December 2009, Citigroup raised $\$ 20.3$ billion by issuing about 24\% new common stock so Citigroup had passed the threshold for a 50\% ownership change. In 2010, Treasury sold all of its 7.7 billion shares of common stock for $\$ 31.85$ billion, a gain of $\$ 6.85$ billion. According to Citigroup:

The common stock issued pursuant to the exchange offers in July 2009, and the common stock and tangible equity units issued in December 2009 as part of Citigroup's TARP repayment, did not result in an ownership change under the Code. $^{14}$

By "ownership change," it referred to the Sec. 382 rule detailed in Sec. III below. It based its claim that the section did not apply to it on the Treasury's "Notices."

After many travails, in January 2011, AIG completed a reorganization that gave Treasury 92.1\% of its common stock. AIG claimed "Deferred tax assets: Losses and tax credit carryforwards" of $\$ 26.2$ billion at the end of 2009. It claimed other valuable tax attributes as well, ${ }^{15}$ including "Unrealized loss on investments" of $\$ 8.7$ billion. These, too, hinged on Notices exempting the firm from the coverage of Sec. 382. AIG acted on the assumption that it had not yet experienced an "ownership change" for tax purposes. It was worried enough about a private-market 50\% ownership change that would invoke Sec. 382, however, that it installed a poison pill to prevent large share purchases.

III. The Law

A. Introduction:

In fact, the law -- arcane in the extreme -- does not grant New GM, Citigroup, or AIG any right to the tax benefits they claim. To be sure, the law lets the GM NOLs survive the Sec. 363 sale in bankruptcy, as we will show. To that extent, New GM did inherit the NOLs. It can continue to use them, however, only so long as the Treasury holds its stock. Once it sells enough of its shares to the public, New GM would by the terms of the statute lose its access to most if not all of the loss carryforwards.

New GM did claim the NOLs, and the Treasury concurred. For 2010 taxes, the NOLs are valid since the government has not yet sold enough of its stock. But if it sells substantially more, New GM will be able to claim the losses only because the Treasury declared that the law did not apply to it. Through a series of "Notices," it claimed that the statutory limitations on the use of NOLs after a defined "ownership change" did not apply if the Treasury owned the stock.

The tax code itself does not differentiate between government and non-government owners. Nonetheless, as we explain in detail later Treasury announced that New GM could continue to claim the NOLs after it sold its stock, and New GM happily deferred.

${ }^{14}$ Richard Murphy, Citi’s deferred tax - an asset of dubious worth,” Tax Research UK: Richard Murphy on Tax and Economics, http://www.taxresearch.org.uk/Blog/2010/09/07/citis-deferred-tax-anasset-of-dubious-worth/ (Sept. 7, 2010).

15 American International Group, Inc., 2009 Annual Report, at 334.http://www.aigcorporate.com/investors/annualreports_proxy.html. "The application of U.S. GAAP requires AIG to evaluate the recoverability of deferred tax assets and establish a valuation allowance, if necessary, to reduce the deferred tax asset to an amount that is more likely than not to be realized (a likelihood of more than 50 percent).” 
First, however, we must explain how New GM could possibly acquire the NOLs in the first place.

\section{B. Cancellation of Indebtedness and Net Operating Losses:}

1. The law as stated. -- (a) Cancellation of debt. Consider first the tax treatment of cancelled debt, relevant here because of the cancellation of Old GM's debt to the Treasury. Suppose a firm has debt outstanding. It negotiates with its creditors, and they agree to trade their debt claims for stock. The firm will have cancellation of indebtedness (COD) income equal to the difference between face amount of the cancelled debt and the market value of the stock distributed. ${ }^{16}$

Now suppose the firm is insolvent. If its creditors swap their claims for stock, under general tax principles it will have COD income. In fact, however, the Internal Revenue Code provides that what would otherwise be COD income will not constitute taxable income. Instead, under Sec. 108 of the code the firm will need to reduce the amount of its other "tax attributes" by the amount of the COD income excluded. Most relevant here, it will need to reduce the amount of its NOLs by the amount of the excluded income. Given that $\$ 1$ of NOL would reduce net taxable income by $\$ 1$, this obviously leaves the firm (in many cases) in much the same position as if it had included the COD income all along. ${ }^{17}$

Finally, suppose the firm is solvent, but files for reorganization under bankruptcy. If as part of its bankruptcy reorganization the creditors swap their claims for stock, the result (for purposes here) is the same as if the firm were insolvent. Under Sec. 108, it can exclude the COD from income, but must offset the excluded amount against its NOLs. ${ }^{18}$

(b) Tax reorganizations. Many reorganizations under the bankruptcy code also constitute "reorganizations" under the tax code. If but only if a transaction qualifies as a "reorganization" under the tax code, a firm that takes the assets of another firm may also take its NOLs. Note that although both the bankruptcy and the tax codes use the term "reorganization," the word refers to different concepts in each. Those concepts are not interchangeable.

In general, reorganizations in bankruptcy are "G reorganizations" under the tax code -- meaning that they fall under Sec. 368(a)(1)(G) of the Internal Revenue Code:

[A] transfer by a corporation of all or part of its assets to another corporation in a title 11 or similar case; but only if ... stock or securities of the corporation to which the assets are transferred are distributed in a transaction which qualifies under section 354, 355, or 356.

Note two points relevant here. First, "Section 363 sales" occur in a "title 11 or similar case." "Title 11" (not "Chapter 11") refers to the Bankruptcy Code, and "section 363" refers not to Sec. 363 of the tax code but to Sec. 363 of the Bankruptcy Code. As a result, if a debtor in possession sells its assets under Sec. 363 it sells its assets in a Title 11 case. In In re Motors Liquidation Co. ${ }^{19}$ the Southern District of New York explicitly

\footnotetext{
${ }^{16}$ I.R.C. Secs. 61, 108(e)(8); U.S. v. Kirby Lumber Co., 284 U.S. 1 (1931).

${ }^{17}$ I.R.C. Sec. 108(a)(1)(B), (b)(2)(A).

${ }^{18}$ I.R.C. Sec. 108(a)(1)(A), (b)(2)(A).

${ }^{19} 430$ B.R. 65 (S.D.N.Y. 2010).
} 
indicated that a Sec. 363 sale (indeed, exactly the GM sale at issue here) could constitute a qualifying $\mathrm{G}$ reorganization. This is the position the Treasury has long taken as well. ${ }^{20}$

Second, Sec. 354 of the tax code requires only that some security holders (not only security holders) of the old firm receive "stock or securities" of the new firm. The section provides: ${ }^{21}$

No gain or loss shall be recognized if stock or securities in a corporation a party to a reorganization ... are ... exchanged solely for stock or securities in ... another corporation a party to the reorganization.

Suppose the creditors to the old firm include both long-term bond holders and trade creditors. Suppose both receive stock in the new firm. The former held "securities" in the old firm, but the latter did not. For at least three decades, the Treasury has taken the position that the transaction qualifies under Sec. 354 even though some of the stock goes to creditors who did not hold securities. Instead, it has argued that a transaction qualifies under Sec. 354 if at least one of the old firm creditors who received stock in the transaction held a security of the old firm. ${ }^{22}$

(c) Net operating losses. Only in a qualifying tax reorganization will a firm that acquires the assets of another also acquire its NOLs. Suppose again that a firm induces its creditors to swap their claims for stock. Suppose further that some NOLs remain after the Sec. 108 adjustments detailed earlier.

Generally, if a debt-for-stock swap occurs as part of a transaction in which a firm sells its assets to another firm, the acquiring firm will not obtain its NOLs too. After all, the losses are specific to the selling firm. The acquiring firm buys the seller's assets, but it does not -- indeed, legally could not -- buy its "tax losses." Conceptually, these tax attributes describe the financial characteristics of a firm; they are not "things" that firms can buy and sell.

Under Sec. 381 of the tax code, however, if one firm buys the assets of another firm in a qualifying tax reorganization, it also acquires its NOLs. More specifically, Sec. 381(a) provides:

In the case of the acquisition of assets of a corporation by another corporation ... in a transfer to which section 361 ... applies, but only if the transfer is in connection with a reorganization described in subparagraph ... (G) of Section 368(a)(1), the acquiring corporation shall succeed to ... the items described in subsection (c) of the ... transferor corporation ...

Note two observations. First, if a firm exchanges its assets for stock as part of a G reorganization, Sec. 361 will apply to the exchange. In turn, that section specifies that the two firms recognize no gain or loss on the transaction. Second, Sec. 381(c)(1) lists "net operating losses." Provided the debt-for-stock swap occurs in a G reorganization, an acquirer takes the seller's NOLs along with its assets.

${ }^{20}$ E.g., Ltr 8503064 (Oct. 24, 1984); Ltr 8521083 (Feb. 27, 1985);

${ }^{21}$ I.R.C. Sec. 354(a).

${ }^{22}$ E.g., Com. Rep. to the Bankruptcy Tax Act of 1980; Ltr 8503064 (Oct. 24, 1984); Ltr 8521083 (Feb. 27, 1985); see generally Carl N. Pickerill, Regarding the Advisability of a Prohibition on the Taxable Asset Sale to Creditors in Bankruptcy, 62 Tax Law. 357, 358 n.3 (2009). 
2. The law applied to GM. Now turn to the reorganization of GM. Insolvent, GM filed for reorganization in bankruptcy court in the Southern District of New York. It sold its assets to a newly formed corporation (New GM) in a Sec. 363 sale. In exchange, it received stock in the new firm which it distributed to its bond holders and other creditors.

Absent Sec. 108, GM would have had COD income equal to the difference between the amount of its debt and the value of the stock it distributed. We will see next, however, that a special provision of the tax code allows a company in bankruptcy to retain its NOLs in full, without having to offset the COD income.

\section{Change in Control:}

1. The law as stated. That, however, is not the end of the story. A firm that buys another firm's assets in a G reorganization cannot necessarily use the transferor's NOLs immediately. To limit "trafficking" in tax losses, Sec. 382 of the tax code limits a buyer's ability to use the NOLs of a "loss corporation" it buys. ${ }^{23}$ The limits apply whenever the stock owned by shareholders holding 5 percent or more in the loss corporation increase by 50 percentage points within a three-year period. ${ }^{24}$ And these limits then restrict the amount of the NOLs that the firm can use to a "section 382 limitation" amount:

[T]he section 382 limitation for any post-change year is an amount equal to --

(A) the value of the old loss corporation, multiplied by

(B) the long-term tax-exempt rate.

Consider how this 382 scheme works. Suppose first that a solvent firm not in bankruptcy convinces its creditors to swap their debt claims for stock. It will recognize COD income. It will apply its NOLs against that income. And if any NOLs remain, then -- if the stock held by 5 percent shareholders increases by at least 50 percentage points -the firm will be able to use only the product of its earlier value and the long-term taxexempt rate. ${ }^{25}$

Suppose second that a firm convinces its creditors to swap their claims for stock in a bankruptcy proceeding. As noted earlier, under Sec. 108 it will not recognize its COD as income but will reduce the amount of its NOLs by the amount of that excluded COD. Importantly, under some circumstances Sec. 382 will not thereafter limit its ability to use its NOLs even if there has been a Sec. 382 change in control. Instead, Sec. 382(l)(5) states that the limits do not apply if (a) the transaction occurs in a title 11 case and (b) "the shareholders and creditors of the old loss corporation ... own ... stock of the new loss corporation" equal to at least 50 percent. ${ }^{26}$ Potentially, NOLs survive bankruptcy proceedings in full.

Suppose third that an insolvent firm does not file for bankruptcy, but still induces its creditors to swap their debt claims for stock. Absent more, according to Sec. 382 its NOLs will disappear. They will disappear because the firm can thereafter only use a

${ }^{23}$ Defined at Sec. 382(k).

${ }^{24}$ I.R.C. Sec. 382(g)(1), (i). A shareholder is a 5 percent shareholder if he holds more than 5 percent either before or after the ownership change. Id., at Sec. 382(g)(2)(B).

${ }^{25}$ I.R.C. Sec. 382(b)(1).

${ }^{26}$ I.R.C. Sec. 382(l)(5) 
portion of its earlier value ("the value of the old loss corporation") -- and Sec. 382 defines that earlier value as "the value of the stock" of the insolvent corporation. ${ }^{27}$ Because the firm was insolvent, its stock was worth nothing (or nearly nothing). The product of the "value of the old loss corporation" and the "long-term tax-exempt rate" will fall to zero, and the NOLs will disappear.

Finally, suppose an insolvent firm does not meet Sec. 382(l)(5)'s 50-percent test. Provided it negotiates its debt-for-stock swap within a bankruptcy filing, under Sec. 382(l)(6) it may add to the value of the firm used to calculate the amount of annual useable NOLs the value created by cancelling the creditors' claims. It can use each year, in other words, a proportional share not just (i) of the value of the pre-reorganization firm but (ii) of that value plus any value attributable to the debt cancellation. ${ }^{28}$

2. The law applied to GM. -- After its Sec. 363 sale, the creditors of Old GM owned 100 percent of the stock of New GM. Under Sec. 382(l)(5), all of its NOLs therefore survived. If the old creditors had obtained less than 50 percent of the stock of New GM, then under Sec. 382(l)(6) New GM would have been able to use only an amount of NOLs calculated by adding the value of the cancelled debt to the value of Old GM.

\section{Later Control Shifts:}

1. The Sec. 382 dilemma. -- Even for New GM, however, Sec. 382 created a risk. First, suppose that New GM tried to avoid all limits on its NOLs through Sec. 382(1)(5). If within two years of the reorganization, the stock owned by any set of 5 percent shareholders increased by 50 percentage points, then the NOLs disappeared. In essence, Subsec. (1)(5) couples its apparent generosity with a draconian penalty: if a firm meets the terms of (l)(5) it enjoys all the NOLs without the standard Sec. 382 reduction, but if it then shifts ownership within two years it loses its NOLs entirely.

Second, even if New GM does not claim the Subsec. (l)(5) benefit, it still jeopardizes much of its NOLs if ownership changes. Suppose New GM did not meet the terms of Subsec. (1)(5) -- suppose, in other words, that it claimed the benefit of Subsec. (1)(6) instead. If within three (not two) years the stock owned by 5 percent shareholders increases by 50 percentage points, then the firm will be able to use only the "section 382 limitation" amount.

The problem for New GM lay in the fact that it exited its G reorganization with the U.S. government holding $61 \%$ of its stock. If the government recovers its investment by selling all of that stock within 2 (for Subsec. (l)(5)) or 3 (for Subsec. (l)(6)) years, it will probably cause a ownership change under the terms of Sec. 382. We say "probably" because we do not know how many other shareholders will trade during the same period. If it does trigger an "ownership change," it will either face the Sec. 382 limits to its NOLs under Subsec. (l)(6), or lose its NOLs entirely under Subsec. (1)(5).

In November 2010 the Treasury did reduce its stake in GM from 61\% to 33\%. Suppose Treasury, or any other large shareholder, transfers an additional $22 \%$ of the stock. Without a special exception, GM will face the Sec. 382 limits on its NOLs.

\footnotetext{
${ }^{27}$ I.R.C. Sec. 382(e)(1).

${ }^{28}$ I.R.C. Sec. 382(l)(6).
} 
The cases of AIG and Citigroup are even clearer. Already, the government has triggered an ownership change in both companies. The Treasury acquired a majority of AIG's stock outright. It acquired enough of Citigroup's stock that combined with Citigroup's new capital issue it caused a 50\% ownership change there too. By the law, both firms should lose their NOLs.

2. The IRS Notices. -- If the Treasury lets a firm claim an NOL to which the law does not entitle it, Treasury merely gives the firm a gift. TARP does authorize Treasury to give gifts. As a result, the superficial choice would seem to be: if Treasury wants to enrich a firm, it can either give it money under TARP or let it take an extra NOL. Either way, it transfers funds from the public fisc to the firm.

To give funds under TARP, however, Treasury must follow statutory guidelines. It must give its gifts in amounts and to firms and for purposes described by Congress in the legislation. When it unilaterally authorizes NOLs, by contrast, it escapes all those Congressional constraints.

And that is exactly what the Treasury did: from 2008 to 2010, it issued a series of "Notices" exempting firms in specified industries from the statutory restrictions under Sec. 382 on the use of NOLs. The statute establishing TARP authorized Treasury to issue "regulations and other guidance" to implement it, ${ }^{29}$ and Sec. 382(m) authorized Treasury to issue the regulations necessary to implement Sec. 382. The Treasury declared those provisions authority enough.

Treasury issued the first of its notices in mid-2008. Notice 2008-76 exempted from Sec. 382 the acquisition of stock of a loss corporation by the U.S. under the Housing and Economic Recovery Act of 2008. ${ }^{30}$ The Notice covered Fannie Mae and Freddie Mac. Notice 2008-83 authorized banks to take certain deductions under 382(h). ${ }^{31}$ Commonly called the "Wells Fargo Ruling," it was predicted to cost the government between $\$ 105$ to $\$ 110$ billion. ${ }^{32}$ The Jones Day law firm estimated its cost at $\$ 140$ billion. $^{33}$ (As we will see, this Notice was terminated, so the actual costs were much smaller.) In Notice 2008-84, the Treasury announced that it would not test for ownership changes on days when the U.S. owned a 50-percent interest in a loss firm. ${ }^{34}$

\footnotetext{
${ }^{29}$ Emergency Economic Stabilization Act of 2008, P.L. 11-0343, 122 Stat. 3765, Sec. 101(c)(5).

30 Notice 2008-76, 2008-39 I.R.B. http://www.irs.gov/irb/200839_IRB/ar01.html\#d0e51(September 29, 2008).

${ }^{31}$ Notice 2008-83, 2008-42 I.R.B. 905 (Sept. 30, 2008).

32 Robert Willens, writing in the Washington Post, http://www.washingtonpost.com/wpdyn/content/article/2008/11/09/AR2008110902155_3.html

${ }^{33}$ The law firm backtracked some months later to defend the Notice strongly and say that it was "quite modest" and "not a significant tax subsidy." See Jones Day, Revisiting Notice 2008-83, http://www.jonesday.com/newsknowledge/publicationdetail.aspx?publication=5711. Jones Day had estimated the Wells Fargo merger alone to have benefitted by some $\$ 25$ billion. The original Jones Day article was taken down from the web, but it is quoted in Washington Post, http://www.washingtonpost.com/wp-dyn/content/article/2008/11/09/AR2008110902155_3.html. Just one other merger, PNC's acquisition of National City, benefited by an estimated 5.1 billion dollars. See Jesse Drucker, PNC Stands to Gain From Tax Ruling; Acquisition of National City Will Bring Billions in Deductions, Experts Say, Wall St. J.

${ }^{34}$ Citation.
} 
Notice 2008-100 declared that an acquisition by Treasury of acquired stock in a loss corporation would not trigger the 382 limitations. ${ }^{35}$ Since Treasury would acquire New GM's Stock in a G reorganization qualifying under Sec. 382(l)(5), GM would escape the Sec. 382 limitations in its initial reorganization anyway. Firms like Citigroup and AIG, however, were not $\mathrm{G}$ reorganizations.

Notice 2009-14 of Feb. 17, 2009 purported to "amplify" 2008-100. ${ }^{36}$ In fact, it explicitly covered the automobile industry, and stated that the Treasury's initial acquisition would not trigger the Sec. 382 limitations. Given that GM used a G reorganization, of course, ultimately it would not need the assurance 2009-14 offered anyway. Notice 2009-38 continued in much the same vein. ${ }^{37}$

Only in January 2010 -- half a year after GM's Sec. 363 sale -- would the Treasury tackle the firm's real Sec. 382 problem: what would happen when Treasury sells its stock? To resolve this question, January 11th's Notice 2010-2 changes the law in two crucial ways. ${ }^{38}$ First:

For purposes of measuring shifts in ownership by any 5-percent shareholder on any testing date occurring on or after the date on which an issuing corporation redeems stock held by Treasury that had been issued to Treasury pursuant to the Programs ..., the stock so redeemed shall be treated as if it had never been outstanding.

Picture the problem. Rather than sell its shares to other investors, the Treasury might sell its shares back to the firm. If it did so, the percentage held by the other investors would - necessarily -- rise. In Notice 2010-2, the Treasury declared that the increase would not trigger Sec. 382. Second:

If Treasury sells stock that was issued to it pursuant to the Programs ... and the sale creates a public group ("New Public Group"), the New Public Group's ownership in the issuing corporation shall not be considered to have increased solely as a result of such a sale.

Even if the Treasury sells its shares to the public, the sale will not trigger Sec. 382. Thus, in Notice 2010-2, the Treasury finally addressed New GM's Sec. 382 problem.

3. The statutory amendment. -- But could the Treasury legally issue Notice 20102 ? Could it legally issue any of these Sec. 382 notices?

Congress objected. It addressed the Treasury's TARP-related Sec. 382 "Notices" in part of the American Recovery and Reinvestment Tax Act of 2009. The issue was addressed in two ways. First, a provision was added to the tax code, Sec. 382(n)(1), to exempt from Section 382 advances of TARP funds which had an explicit requirement for a restructuring plan:

The limitation contained in subsection (a) shall not apply in the case of an ownership change which is pursuant to a restructuring plan of a taxpayer which-

\footnotetext{
${ }^{35}$ 2008-44. I.R.B. 1081.

${ }^{36}$ 2009-7 I.R.B. 516.

${ }^{37}$ Citation.

${ }^{38}$ www.irs.gov/irb/2010-02_IRB/ar09.html.
} 
(A) is required under a loan agreement or a commitment for a line of credit entered into with the Department of the Treasury under the Emergency Economic Stabilization Act of 2008, and

(B) is intended to result in a rationalization of the costs, capitalization, and capacity with respect to the manufacturing workforce of, and suppliers to, the taxpayer and its subsidiaries.

(2) SUBSEQUENT ACQUISITIONS.-Paragraph (1) shall not apply in the case of any subsequent ownership change unless such ownership change is described in such paragraph.

Second, the Act authorized the Wells Fargo notice as far as bank mergers that happened before January 16, 2010, but not afterwards. The bill explains that this was because though Congress found Treasury's various TARP notices outrageous but thought it should save taxpayers who relied on them anyway. The bill states: ${ }^{39}$

Congress finds as follows:

(1) The delegation of authority to the Secretary of the Treasury, or his delegate, under section 382(m) does not authorize the Secretary to provide exemptions or special rules that are restricted to particular industries or classes of taxpayers;

(2) Internal Revenue Service Notice 2008-83 is inconsistent with the congressional intent in enacting such section 382(m);

(3) the legal authority to prescribe Notice 2008-83 is doubtful;

(4) however, as taxpayers should generally be able to rely on guidance issued by the Secretary of the Treasury, legislation is necessary to clarify the force and effect of Notice 2008-83 ....

4. Notice 2010-2. -- Now return to Notice 2010-2, and ask the obvious question: given Sec. 382(n), why did Treasury issue the Notice? Treasury issued the Notice because Subsec. (n) did not cover a sale by the Treasury to the public. Subsec. (n)(1)(A) may have covered the Treasury's initial stock acquisition. After all, the Treasury took its equity interest as part of its TARP investment, so perhaps it "required" the stock "under a loan agreement." Ironically, however, Treasury did not need Sec. 382(n) for GM -- after all, GM restructured itself as a G reorganization. And Sec. 382(n) was not applicable to the purchases of equity in Citigroup and AIG, because they were financial firms rather than manufacturers.

Yet Sec. 382(n)(1) did not protect GM from Treasury's re-sale of the stock it acquired. When Treasury lent GM the money, it did not "require" its own re-sale under the loan agreement. It would be an odd agreement that required the lender to sell any stock it obtained. And if it did not require the re-sale, then Sec. 382(n)(1) did not exempt Treasury's sale of its shares to the public from the Sec. 382 limitations.

This problem placed Treasury in a bind. Congress claimed not to like the way Treasury had helped the financial institutions. It explicitly declared that it had not authorized Treasury to issue the Notices. But absent a Notice, Treasury would trigger the Sec. 382 limitations at GM when it sold its stock.

\footnotetext{
${ }^{39}$ P.L. 111-5 (American Recovery and Reinvestment Tax Act of 2009) (paragraph indentation added).P.L. 111-5, section 1261.
} 
Apparently, Treasury responded: "Congress be damned." To move $\$ 18$ billion to New GM, it needed to be able to assure the firm and its investors that GM would continue to have access to the accumulated losses after Treasury sold its stock. Sec. 382(n) did not offer that assurance. Through Notice 2010-2, Treasury offered it anyway.

IV. Rationale, Deference, and Reliance:

A. A Rationale for the Notices?

Treasury does not explain why the Notices promote the policy behind Sec. 382, but consider one line of argument:

The claim: The purpose of Section 382 is to prevent Company $\mathrm{X}$ from buying Company $\mathrm{Y}$ for the main purpose of reducing Company $\mathrm{X}$ 's corporate income tax, rather than for any real business purpose. The Treasury is not buying GM to reduce taxes, and neither will the investors who buy the shares from the Treasury. Given the absence of any "trafficking" in tax attributes, the Secretary of the Treasury can properly use his general rulemaking authority to exempt the transaction from Sec. 382.

This is unsatisfactory. The Treasury does not pay taxes, but the other investors in New GM do. For them, the ability to invest in a company that earns its income tax-free for the indefinite future is a major advantage.

What is more, the purpose behind a section does not matter when its language is clear. Sec. 382 routinely covers transactions not motivated by tax avoidance, and the Treasury does not exempt them from the section by appealing to "purpose." Sec. 382 covers non-abusive transactions because it is, at root, a "prophylactic rule." By their very nature, prophylactic rules cover transactions one would not necessarily cover if "purpose" were all that mattered.

That the government buys stock does not itself imply that different ownership change rules should apply. The U.K., for example, imposes a rule similar to Sec. 382. It does not make special allowance for government-owned stock. As KPMG explained:

The UK tax code contains similar provisions preventing the carry forward of losses following a 50 percent or more ownership change, but only when there is a 'major change in the nature or conduct of the trade' within three years of the change of ownership. But, in contrast to the position in the US, the acquisition of shares by the UK government does count in measuring whether there has been an ownership change. ${ }^{40}$

The U.S. statute does not exempt government-owned stock, and neither does the U.K.'s.

Ultimately, tax benefits did play a major role in these transactions. By letting New GM keep NOLs to which it was not legally entitled, Treasury gave the firm (and its owners, including the UAW) \$18 billion more in assets. Had the President tried to give GM \$18 billion forthrightly, voters might have complained. By hiding the gift in an obscure tax section, he reduced that electoral scrutiny. But the investors who bought New GM shares noticed. They paid a higher price than they otherwise would have

40 KPMG, Frontiers in Tax: people thinking beyond borders in financial services, at http://www.kpmg.com/Global/en/IssuesAndInsights/ArticlesPublications/Pages/Frontiers-in-Tax-Peoplethinking-beyond-borders.aspx (July 2010). 
paid. ${ }^{41}$ And necessarily, the UAW, the government of Canada, and the former bondholders also noticed.

\section{B. Court Deference:}

The executive branch continually interprets statutes as it issues regulations. Courts do too, and often announce interpretations that outsiders like ourselves consider ridiculous. Nonetheless, we give courts the final word in interpretation. Could it be that in tax law, the executive branch has the final word? In fact, courts have ruled -- sensibly -- that it does not. Although courts often defer to executive branch interpretations of statutes, they do not defer in the circumstances of something like the TARP Notices.

On January 11, 2011, the U.S. Supreme Court in Mayo Foundation v. U.S., made clear that courts should treat tax regulations no differently than any other regulations. ${ }^{42}$ The case concerned a statute that exempted students from FICA withholding. In 2004, the Treasury promulgated regulations announcing that medical residents were not students. The Mayo clinic challenged the regulation, and the Court held it valid. Courts should treat tax regulations like any other, it explained.

Under the well-known "Chevron" rule by which courts sometimes defer to executive agencies, ${ }^{43}$ explained the Supreme Court, courts should first ask whether Congress had "directly addressed the precise question at issue." If not, then they should defer to the agency unless the rule was "arbitrary or capricious in substance, or manifestly contrary to the statute." 44 It would not, the Supreme Court explained, "carve out an approach to administrative review good for tax law only. ... The principles underlying our decision in Chevron apply with full force in the tax context." 45

Nonetheless, this deferential standard applies only when Congress intended to delegate to an agency, and the agency followed standard rule-making procedures. Continued the Court: ${ }^{46}$

We have explained that "the ultimate question is whether Congress would have intended, and expected, courts to treat [the regulation] as within, or outside, its delegation to the agency of 'gap-filling' authority." [Long Island Care at Home, Ltd. v. Coke, 551 U.S. 157, 173 (2007)]. In the Long Island Care case, we found that Chevron provided the appropriate standard of review "[w]here an agency rule sets forth important individual rights and duties, where the agency focuses fully and directly upon the issue, where the agency uses full notice-and-comment procedures to promulgate a rule, [and] where the resulting rule falls within the statutory grant of authority." 551 U.S., at 173 ....

Notice 2010-2 fails both of these requirements. First, Congress explicitly declared that it did not intend to delegate the authority that Treasury claimed. Notice

${ }^{41}$ Note that this reduces the net cost to the government of the Notice -- since the Treasury will be able to re-sell its shares at a higher price.

${ }^{42}$ Mayo Foundation for Medical Education \& Research v. U.S., 131 S. Ct. 704 (2011).

${ }^{43}$ Chevron U.S.A. Inc. v. Natural Resources Defense Council, 467 U.S. 837 (1984).

${ }^{44}$ Mayo, 131 S. Ct. at 711.

${ }^{45}$ Mayo, 131 S. Ct. at 713.

${ }^{46}$ Mayo, 131 S. Ct. at 714. 
2010-2 applied only to financial institutions, automobile companies, and other specific TARP recipients. Yet "section 382(m) does not authorize the Secretary to provide," Congress announced, "special rules that are restricted to particular industries or classes of taxpayers." When Treasury did exactly that in TARP Notice 2008-83, it acted in a way that was "inconsistent with the congressional intent" and of "doubtful" "legal authority." Notice 2010-2 is precisely the industry-specific TARP notice Congress denounced.

Second, Notice 2010-2 is not a regulation. It is a "notice," and the distinction matters. The Mayo Court declared Chevron appropriate when an agency used "full notice-and-comment procedures to promulgate a rule." By contrast, the Supreme Court explained in Christiansen v. Harris County: ${ }^{47}$

Interpretations such as those in opinion letters --like interpretations contained in policy statements, agency manuals, and enforcement guidelines, all of which lack the force of law -- do not warrant Chevron-style deference. Instead, interpretations contained in formats such as opinion letters are [governed by Skidmore].

In turn, in Skidmore v. Swift \& Co.., ${ }^{48}$ the Supreme Court had considered the agency's logic, but then decided the question for itself:

We consider that the rulings, interpretations and opinions of the Administrator ... constitute a body of experience and informed judgment to which courts and litigants may properly resort for guidance. The weight of such a judgment in a particular case will depend upon the thoroughness evident in its consideration, the validity of its reasoning, its consistency with earlier and later pronouncements, and all those factors which give it power to persuade, if lacking power to control.

In Notice 2010-2, Treasury did not try to reason or persuade. It simply declared the rule so.

\section{Taxpayer Reliance:}

Suppose the TARP Notices are invalid. Should taxpayers be able to rely on them anyway, since their invalidity was the fault of Treasury rather than the taxpayer? ${ }^{49}$ Notice 2010-2 provides:

Taxpayers may rely on the rules described in Section III of this notice.

These rules will continue to apply unless and until there is additional guidance.

This is profoundly self-serving, of course. The Treasury cannot change the law by fiat. A bureaucrat cannot give his friend funds illegally, and then protect that friend by declaring his friend's reliance protected. If a court held Notice 2010-2 illegal, GM could not cite the Notice as authority for deducting \$45 million in NOL's anyway.

${ }^{47}$ Christiansen v. HarrisCounty, 529 U.S. 576 (2000).

${ }^{48}$ Skidmore v. Swift \& Co., 323 U.S. 134, 140 (1944).

${ }^{49}$ Before the Treasury and other owners (including the $10 \%$ given to Old GM) sell enough stock to trigger the 50\% threshold, use of the NOL's would be legal even without Notice 2010-2. GM is now, however, a publicly traded company and has told the public that the NOL's are part of its assets, though without 2010-2 they will not be if the Treasury sells its stake.Thus, the immediate question would be whether GM has thereby violated federal securities laws. 
The relevant question goes to penalties: may a taxpayer who relies on the Notices avoid civil and criminal penalties? As Cheryl Block explains: ${ }^{50}$

As with revenue rulings and revenue procedures, announcements and notices can provide substantial authority sufficient to relieve taxpayers from the negligence and substantial understatement penalties and, consequently, may be relevant to whether certain penalty provisions apply.

Sec. 6662 of the tax code imposes a penalty for any "substantial understatement of income tax." Subsec. (d)(2)(B) protects a taxpayer who relies on "substantial authority." According to the Treasury, its own "Notices" are "substantial authority,"51 though it also explains the "weight accorded an authority depends on its relevance and persuasiveness." 52

Consider the weight appropriate to Notice 2010-2. First, the Treasury itself declares it "substantial authority." This is of course again self-serving. Acting on behalf of the Administration, the Treasury has manipulated tax procedure to route $\$ 18$ billion to its supporters. In essence, it then claims that its manipulation insulates those favored taxpayers from "substantial underpayment" penalties.

Second, Notice 2010-2 does not much try to persuade. It simply declares. But if an IRS notice were to announce that Microsoft did not have to pay taxes because Bill Gates paid the Treasury Secretary $\$ 1$ million in bribes, the announcement would hardly give Microsoft substantial authority. Here, the Democratic administration has given a massive tax benefit to one of the party's biggest supporters. Like other labor unions, the UAW provided the Obama campaign with elaborate assistance. Some of the help came in person, and some came as money. From 1989 to 2010, the UAW spent over \$27 million on political campaigns, 98 percent of it on behalf of the Democratic party. ${ }^{53}$ In 2008 alone, it spent $\$ 2,119,937$ on political campaigns, $\$ 2,101,187$ of that for Democrats. $^{54}$

Suppose that Notice 2010-2 had stated:

The President is grateful to the UAW for the assistance it provided his party. In gratitude for that political support, the Treasury announces that, should it sell the stock that was issued to it pursuant to the Programs ... and should the sale create a public group ("New Public Group"), the New Public Group's ownership in the issuing corporation shall not be considered to have increased solely as a result of such a sale.

The only difference between this hypothetical notice and the real Notice 2010-2 is explicit character of the reason for the largesse. It is an odd approach to statutory

\footnotetext{
${ }^{50}$ Cheryl Block, citation.
}

51 Mitchell Rogovin\& Donald Korb, The Four R's Revisited: Regulations, Rulings, Reliance, and Retroactivity in the 21st Century: A View from Within, 46 Duquesne L. Rev. 223 (2008); Reg. 1.66624(d)(3)(iii).

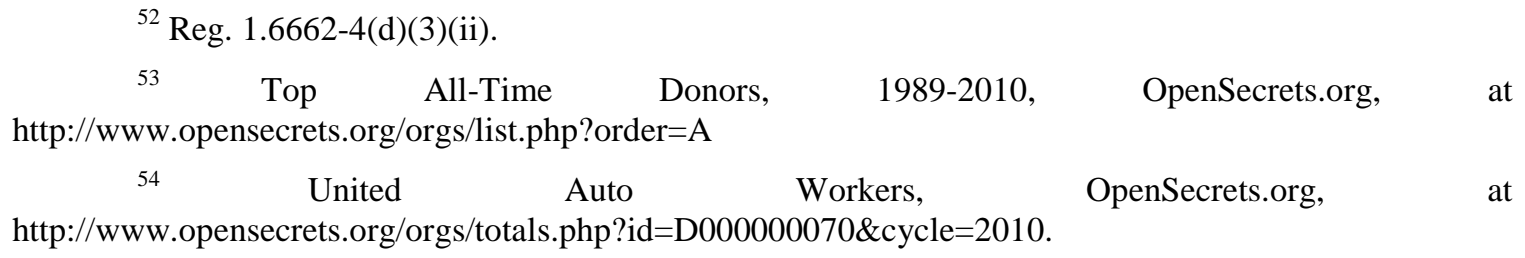


interpretation that would make a Notice illegal if articulated its reason, but legal if it left the reason unsaid.

V. Legislative Resolution

A. Introduction:

The problem at stake concerns the manipulation of highly arcane minutiae in the corporate tax law to route huge sums to politically favored parties. The question is what anyone can do about it.

Political remedies are unlikely to work. Voters do not understand transactions like this well enough to punish a candidate in the next election. Much less will they impeach anyone for a transaction like this. Voters understand politicians who take briefcases stuffed with cash; they do not understand G reorganizations and NOL carryforwards. Congress has complained, asking TARP's Inspector-General to investigate the validity of the Notices and their motivation. ${ }^{55}$ Senator Jim Bunning even introduced a bill with the sole purpose of repealing Notice 2010-2. ${ }^{56}$ Unless Congress can override the Notices by a veto-proof 2/3 majority, however, all it can do is badger the Administration with its oversight authority and complain to the public.

B. The Standing Problem:

All this leaves a lacuna in the law. As the GM Notices illustrate, it leaves an \$18 billion lacuna. To explore how Congress might address the problem, consider the following fantasy IRS Notice:

Internal Revenue Bulletin: 2010-999

February 24, 2011

Notice 2011-999

Application of Title 26 to Certain Persons Pursuant to the Emergency Economic Stabilization Act of 2008

\section{BACKGROUND}

Section 7805(a) of the Internal Revenue Code ("the Code") provides that except where such authority is expressly given to any person other than an officer or employee of Treasury, the Secretary shall prescribe all needful rules and regulations for the enforcement of Title 26, including all rules and regulations as may be necessary by reason of any alteration of law in relation to internal revenue.

\footnotetext{
${ }^{55}$ Office of the Special Inspector General for the Troubled Asset Relief Program, Engagement Memo - Review of the Section 382 Limitation Waiver for Financial Instruments Held by Treasury (Aug. 10, 2010)

www.sigtarp.gov/reports/audit/2010/Engagement\%20Memo\%20-

\%20Review\%20of\%20the\%20Section\%20382\%20Limitation\%20Waiver\%20for\%20Financial\%2 0Instruments\%20Held\%20by\%20Treasury.pdf

${ }^{56}$ S. 2916 [111th], A bill to provide that Internal Revenue Service Notice 2010-2 shall have no force and effect... The bill was sent to committee and never returned.
} 
Section 101(c)(5) of EESA provides that the Secretary is authorized to issue such regulations and other guidance as may be necessary or appropriate to carry out the purposes of EESA.

\section{GUIDANCE REGARDING A CERTAIN PERSON}

Any funds received by J. Mark Ramseyer or Eric B. Rasmusen shall not constitute "income" under Sec. 61 of the I.R.C., and shall be entirely exempt from taxation.

\section{DRAFTING INFORMATION}

The principal author of this notice is John B. Doe of the Office of Associate Chief Counsel (Individual). For further information regarding this notice, contact Robert B. Roe at (202) 999-9999 (not a toll-free call).

Few readers would dispute the notion that Notice 2011-999 straightforwardly violates the Code. It does not even try to argue that sparing us from the income tax furthers the purposes of the EESA. Even if it did, you (the reader) would laugh. But you could not laugh in court. You would not have standing.

Under current law, voters also cannot challenge these TARP arrangements in court. $^{57}$ If a rule benefits some people but does not harm others, nobody will have "standing" to challenge it. Justice Powell articulated the point most famously: ${ }^{58}$

I cannot now imagine a case, at least outside the First Amendment area, where a person whose own tax liability was not affected ever could have standing to litigate the federal tax liability of someone else.

A more recent example of the rule appeared in the Chrysler case. ${ }^{59}$ There, Justice Roberts held is that taxpayers lacked standing to challenge other people's tax benefits. The plaintiffs argued that Chrysler's tax breaks hurt them:

Plaintiffs principally claim standing by virtue of their status as Ohio taxpayers, alleging that the franchise tax credit "depletes the funds of the State of Ohio to which the Plaintiffs contribute through their tax payments" and thus "diminishes the total funds available for lawful uses and imposes disproportionate burdens on' them."

Justice Roberts said no:

As an initial matter, it is unclear that tax breaks of the sort at issue here do in fact deplete the treasury: The very point of the tax benefits is to spur economic activity, which in turn increases government revenues.

Plaintiffs' alleged injury is also "conjectural or hypothetical" in that it depends on how legislators respond to a reduction in revenue, if that is the consequence of the credit. Establishing injury requires speculating that elected officials will increase a taxpayer-plaintiff's tax bill to make up a deficit;

57 A good discussion appears in Kristin E. Hickman, A Problem of Remedy: Responding to Treasury's (Lack of) Compliance with Administrative Procedure Act Rulemaking Requirements, 76 Geo. Wash. L. Rev. 1153 (2008).

\footnotetext{
${ }^{58}$ Simon v. E. Ky. Welfare Rights Org., 426 U.S. 26, 46 (1975)(Powell, J., concurring).

${ }^{59}$ DaimlerChrysler Corp. v. Cuno, 547 U.S. 332 (2006).
} 
establishing redressability requires speculating that abolishing the challenged credit will redound to the benefit of the taxpayer because legislators will pass along the supposed increased revenue in the form of tax reductions. Neither sort of speculation suffices to support standing.

Various authors propose reforms to the standing rules. ${ }^{60}$ Unfortunately, their proposals simultaneously increase the incidence of frivolous suits, venue shopping, and collusive litigation. ${ }^{61}$ In the name of policing frivolous litigation, GM (and Ramseyer and Rasmusen) keep their special deals. Although Treasury cannot get away with arbitrary interpretations of the statutes that increase someone's taxes (since that person would have standing to object in court), it can get away with equally unreasonable interpretations that reduce someone's taxes.

\section{Two Alternatives:}

1. Congressional litigants. -- To limit Treasury's ability to offer special deals to political favorites (GM, Ramseyer-Rasmusen), we offer two alternatives that might yet constrain the risk of frivolous suits. First, Congress could offer standing to members of Congress:

\section{Tax Regulation Enforcement Bill}

Any two members of Congress shall have standing to challenge in court any interpretative or other notices, rules, regulations, or guidelines of the Internal Revenue Service as contrary to statute. The members bringing the action need not be current members of Congress and need not have voted for or against the statute in question. Should they win, they shall each be entitled to liquidated damages of $\$ 1,000$, plus reasonable compensation for their legal fees and any other costs they may incur.

Any number of these suits may be filed concurrently. Any district court of the United States shall have jurisdiction.

Requiring two Congressmen rather than one will help to reduce the number of frivolous suits. We originally thought to propose five rather than two, but recalled how in Vichy in 1940 the resolution that France needed a new constitution passed by 395 to 3 in the Chamber of Deputies and 229 to 1 in the Senate. ${ }^{62}$

Allowing more than one suit and in different courts will prevent collusive suits that block review. If only the Tax Court had jurisdiction, for example, then a proTreasury plaintiff could bring suit there, "take a dive," and refrain from appealing -thereby blocking a real plaintiff. ${ }^{63}$

${ }^{60}$ Joshua D. Rosenburg, The Psychology of Taxes: Why They Drive Us Crazy, and How We Can Make Them Sane, 16 Va. Tax L. Rev. 155 (1996) (recommending action modeled on qui tam in tax context).

${ }^{61}$ See Maxwell L. Stearns, Standing Back from the Forest: Justiciability and Social Choice, 83 Cal. L. Rev. 1309 (1995).

${ }^{62}$ William L. Shirer, The Collapse of the ThirdRepublic 933 (1969). Two Socialist and one Radical deputy voted against; the only dissenting senator was the right-wing Marquis de Chambrun.

${ }^{63}$ Note that Congress cannot completely delegate the executive power to enforce the laws. In Unique Product Solutions, Ltd. v. Hy-Grade Valve, Inc. (February 23, 2011, N.D. Ohio), the court held that the President could not give a private plaintiff complete authority to pursue a criminal case against someone who labeled a product as patented after the patent expired. To do so was, it explained, an 
2. Qui tam statute. -- An alternative to allowing Congressmen to challenge Treasury Notices would be a qui tam statute. A short version might go as follows:

A Qui Tam Tax Regulation Enforcement Bill

It shall be illegal for any employee of the Treasury Department to misinterpret a federal statute. Any employee found willfully to have misinterpreted a statute shall pay a civil fine of \$500. Any two members of Congress may bring a civil action against such violator in any District Court of the United States and obtain plus reasonable compensation for their legal fees and any other costs they may incur.

Conceptually, the qui tam statute performs the same function as the standing rule. Either version enables two members of Congress to file suit to challenge any action by the Treasury to route funds to politically favored institutions.

\section{Conclusions}

Having the authority to issue tax regulations is a power of the President that is peculiarly tempting for abuse. I.R.S. Notice 2010-2 and its predecessors illustrate the problem. There, Treasury exempted companies partly owned by the government from taxes they would have had to pay had their owners been entirely private. The politics involved is clearest with GM. There, the bailout transferred enormous wealth to labor union closely allied to the party in power.

GM will not need the special notice if the government refrains from selling its ownership for long enough. The notices also apply to AIG and Citigroup, however. Because these companies never entered bankruptcy court, even the initial government share purchases raise a problem.

Preventing politically driven largesse like Notices 2010-2 is hard. Because they will need 2/3 support in the Senate and House to override a Presidential veto, Congressmen cannot readily invalidate illegal executive interpretations. Instead, they will need to turn to the courts. Yet under current law no one has standing to challenge tax interpretations that benefit a few taxpayers at the expense of the many. We proposed one solution: give Congressmen standing to contest agency interpretations in court.

unconstitutional delegation of the President's duty to "take care" that the laws be faithfully executed. http://ia700409.us.archive.org/4/items/gov.uscourts.ohnd.168384/gov.uscourts.ohnd.168384.18.0.pdf . 